\title{
The workload of fishermen: a cross sectional survey among Danish commercial fishermen
}

\author{
Helle Østergaard ${ }^{1}$, Jørgen Riis Jepsen ${ }^{1}$, Gabriele Berg-Beckhoff ${ }^{2}$ \\ ${ }^{1}$ Centre of Maritime Health and Society, University of Southern Denmark, Esbjerg, Denmark \\ ${ }^{2}$ Unit for Health Promotion Research, University of Southern Denmark, Esbjerg, Denmark
}

\begin{abstract}
Background: Fishery has always been perceived as a physically demanding industry of a manual character. In recent years the physical work environment has developed positively and consequently the current situation in not fully described in the existing literature. This study aims to describe the work environment of Danish fishermen with regard to their physical workload and ergonomic factors.

Materials and methods: A cross sectional study was performed on a random sample of active Danish commercial fishermen (response rate: 28\%) by means of a questionnaire on demographic and self-reported occupational and health data. Questions covering the physical workload were related to seven different work situations and a score summing up the workload was developed for the analysis of the relative impact on different groups of fishermen.

Results: Almost all fishermen (96.2\%) were familiar to proper lifting techniques but only 55.4\% used them in their daily work. Standing work was the most applied work position (81.8\%), while repetitive hand and finger movements and twisting and bending in the back were other frequent work situations. Deckhands had higher workload scores than skippers, while crew on Danish seiners had higher workload scores than fishermen in other vessel types.

Conclusions: Despite improved work environment in the Danish fishing industry, fishermen still experience high levels of workload and suboptimal ergonomic conditions, which are known to cause pain and impair musculoskeletal health. To address the specific areas of fishing with the highest workload, future investments in assistive devices to ease the demanding work and reduce the workload, should particularly address deckhands and less mechanized vessels.
\end{abstract}

(Int Marit Health 2016; 67, 2: 97-103)

Key words: occupational health, ergonomics, fishery, cross sectional study

\section{INTRODUCTION}

The fishing industry has formerly been perceived as a particularly dangerous and physically demanding work and studies throughout the 1990's, and most recently in 2008 , have observed a continued excessive risk of certain health effects [1], especially musculoskeletal disorders and accidents [2, 3]. Although recent studies indicate that there has been a positive development of the physical work environment on board fishing vessels [4-6], the work is still characterized by frequent manual handling of catch (lift, push and pull) and heavy equipment in wet, slippery and mobile environments [6,7].

The space on board the fishing vessels is often limited, and this restriction poses challenges in ensuring optimal working situations and varied working postures for the fishermen. Furthermore, the vessels' movements are influenced by the impact of waves, which also presents a challenge and increases the risk of injury. Sudden movements can make it difficult to predict the weight of equipment when lifting or pushing and combined with a cold and wet working

Cand. scient. san. publ. Helle Østergaard, Centre of Maritime Health and Society, University of Southern Denmark, Niels Bohrs Vej 9, 6700 Esbjerg, Denmark,

tel: +45 6550 4266, fax: +45 6550 4283, e-mail: hoestergaard@health.sdu.dk 
environment, this can affect the musculoskeletal system $[6,8]$. In addition to these risk factors, fishermen are exposed to numerous other influences that are believed to have negative consequences for the development of musculoskeletal disorders. These include an increased risk of accidents, low frequency vibration, draft and cold, and monotonous work [8-10]. These exposures are all part of the daily life for the fishermen, who are consequently likely to have a significant risk of inexpedient loadings and overloads resulting in musculoskeletal health effects.

The ergonomic work environment of the fishermen on board Danish fishing vessels is only described to a limited extent. Furthermore, various technological and organisational changes in contemporary fishing over the past decades mean that the current situation is not fully reflected in the existing literature.

The aim of this study is to describe the ergonomic work environment of Danish fishermen with regard to the level of the physical workload and the ergonomic work environment related to work on Danish fishing vessels. The different occupational groups on board, the type of vessels, and the number of days at sea will also be taken into account. This understanding should contribute to further optimisation of the work environment, particularly regarding ergonomic factors in the fishing industry.

\section{MATERIALS AND METHODS}

As a part of a project funded by the European Fisheries Fund (journal. no. 33010-13-k-0264), a study was performed among Danish active commercial fishermen. The project contained two components, out of which one was a cross-sectional study. In August 2015, a detailed literature review and an analysis of the results from the cross-sectional study was published [11].The Danish AgriFish Agency (NaturErhvervstyrelsen) provided a register with all Danish active commercial and sideline fishermen and a survey was conducted between February and April 2015. A random sample of 2500 active commercial (full-time) fishermen out of 5809 fishermen received the questionnaire by post, with the option to return the questionnaire either by mail or online. An additional reminder was sent out to fishermen who did not answer the first time.

Figure 1 shows a flow chart of the study population. Answers were collected from 637 participants, resulting in a response rate of $28 \%$. Due to a high number of ceased fishermen, data from 270 fishermen was included in the

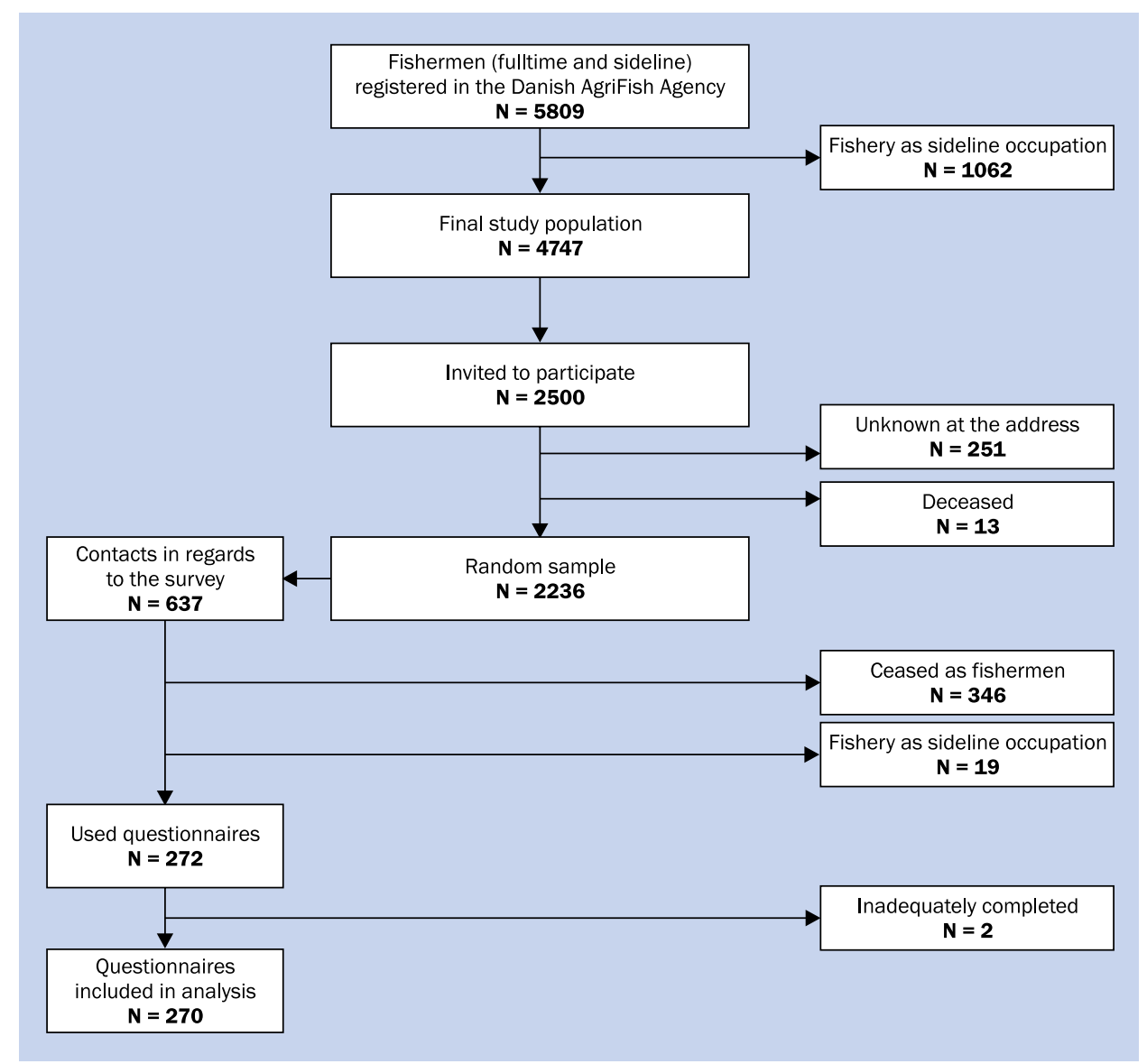

Figure 1. Flowchart of study population 
analysis. The questionnaire contained 93 questions addressing demographic and self-reported occupational and health data.

The questions covering physical workload were developed in the FINALE project by Holtermann et al. 2010 [12] and relate to seven different work postures: standing, pushing or pulling, carrying or lifting, hands lifted above shoulder height, back sharply bent forward without support of hands and arms, twisting and bending in the back, same hand and finger movements repeatedly. The questions covered the extent of these work postures during active work hours. A score that summed up all 7 questions was developed for the analysis, going from 7 to 42 , where the high score equals greater workload for the fisherman. Conditional missing imputation was used if 2 questions or less were missing in the answers. The missing was found from the mean value of the remaining questions from the specific person. The Cronbachs alpha coefficient of 0.81 showed good internal consistency of the scale [13].

The fishermen were additionally asked to answer whether they worked as skipper or deckhands on board and on which type of vessel. The most common vessels were included and divided into 4 categories: Trawlers, Danish seiners, Netters and Liners, and Potters. They were also asked to state the typical number of days fishing, with categories split into: 1 day, 1-7 days and more than 7 days. Additional questions relating to work included the number of years working as fishermen and one's involvement in a sideline occupation (yes or no). The socio-demographic questions included age, body mass index (BMl; from weight $[\mathrm{kg}] /$ height $[\mathrm{m}]^{2}$ categorised into normal $\left(\mathrm{BMI}<25 \mathrm{~kg} / \mathrm{m}^{2}\right)$, overweight $\left(25-30 \mathrm{~kg} / \mathrm{m}^{2}\right)$ and obese $\left(>30 \mathrm{~kg} / \mathrm{m}^{2}\right)$, smoking status (yes/no), level of education (unskilled worker, skilled worker and higher education). Furthermore, the fishermen were asked to rate their self-perceived health. Questions covering work conditions for standing work and lifting work presented the response options of yes/no.

Data from the questionnaires were entered into a computerised database (SurveyXact) and simple descriptive statistics were conducted in STATA 14.0. The model assumptions for the workload score are checked and fulfilled thus ANOVA is applied.

\section{RESULTS}

Table 1 describes the work characteristics of the fishermen included in the analysis $(n=270)$. More than half of the fishermen were skippers (61.9\%), while the remaining $38.2 \%$ were categorised as deckhands, which include all other job categories on board the vessels (deckhands, trainees, cooks) and missings. The most common vessel type was trawlers (43.7\%) and about half of the fishermen typically spent one day at a time at sea. On average, the respondents had worked 30.8 years as fishermen, while
Table 1. Work characteristics of Danish fishermen - cross sectional survey 2015

\begin{tabular}{|c|c|c|}
\hline & $\mathbf{N}$ & $\%$ \\
\hline \multicolumn{3}{|l|}{ Occupational group: } \\
\hline Skipper & 167 & 61.9 \\
\hline Deckhands* & 103 & 38.2 \\
\hline \multicolumn{3}{|l|}{ Vessel type: } \\
\hline Trawler & 118 & 43.7 \\
\hline Danish seiners & 14 & 5.2 \\
\hline Netters and liners & 75 & 27.8 \\
\hline Potters & 28 & 10.4 \\
\hline Others** & 35 & 13.0 \\
\hline \multicolumn{3}{|c|}{ Number of days at sea: } \\
\hline 1 & 124 & 48.1 \\
\hline $1-7$ & 90 & 34.9 \\
\hline More than 7 & 44 & 17.1 \\
\hline \multicolumn{3}{|c|}{ Number of years as fisherman: } \\
\hline$<10$ & 23 & 8.9 \\
\hline $10-19$ & 37 & 14.3 \\
\hline $20-29$ & 37 & 14.3 \\
\hline $30-39$ & 79 & 30.6 \\
\hline$\geq 40$ & 82 & 31.8 \\
\hline \multicolumn{3}{|c|}{ With sideline occupation": } \\
\hline Yes & 62 & 24.1 \\
\hline No & 195 & 75.9 \\
\hline
\end{tabular}

*Includes all other job categories (deckhands, trainees, cooks and missings);

**Includes purse seiners and multi-purpose vessels, other vessels and missings; 'Missings: 12; "Missings: 13

almost a fourth (24.1\%) indicated that they have a sideline occupation as e.g. craftsman, beekeeper etc.

The demographic distribution in Table 2 shows a mean age of fishermen at 53.1 years $(S D=13.5$, range $17-80$ ) and all respondents were male. Generally, the group was characterised as unskilled workers (54.2\%), overweight or obese $(46.4 \% / 32.2 \%$, respectively), and perceived their own health as good (62.6\%).

Table 3 shows the distribution of work positions for the fishermen. The distribution of each of the 7 positions illustrates work situations with an extension of more than half the of the fishermen's work time. $81.8 \%$ of the respondents spent more than half of their work time standing, while same repeated hand and finger movements were performed in more than half of their worktime by $72.8 \%$ of the fishermen. Twisting and bending in the back (43.7\%) and carrying or lifting (36.2\%) were other frequent work situations.

According to observations regarding the distribution of the workload score (Table 4) for the occupational groups, deckhands have higher workload scores compared to skip- 
Table 2. Socio-demographics of Danish fishermen - cross sectional survey 2015

\begin{tabular}{|c|c|c|c|c|c|c|c|}
\hline & \multicolumn{2}{|l|}{ All } & \multicolumn{2}{|c|}{ Skippers } & \multicolumn{2}{|c|}{ Deckhands } & \multirow[t]{2}{*}{ P* } \\
\hline & $\mathbf{N}$ & $\%$ & $\mathbf{N}$ & $\%$ & $\mathbf{N}$ & $\%$ & \\
\hline Agel: & & & & & & & 0.002 \\
\hline$<30$ years & 20 & 7.5 & 6 & 3.6 & 14 & 13.6 & \\
\hline $30-40$ years & 21 & 8.2 & 12 & 7.3 & 10 & 9.7 & \\
\hline $41-50$ years & 54 & 20.2 & 42 & 25.5 & 12 & 11.7 & \\
\hline $51-60$ years & 82 & 30.6 & 45 & 27.3 & 37 & 35.9 & \\
\hline$\geq 60$ years & 90 & 33.6 & 60 & 36.4 & 30 & 29.1 & \\
\hline Education": & & & & & & & 0.232 \\
\hline Unskilled worker & 142 & 54.2 & 80 & 50.0 & 62 & 60.8 & \\
\hline Skilled worker & 69 & 26.3 & 46 & 28.8 & 23 & 22.6 & \\
\hline Higher education & 51 & 19.5 & 34 & 21.3 & 17 & 16.7 & \\
\hline Body mass index"II: & & & & & & & 0.623 \\
\hline Normal weight $\left(<25 \mathrm{~kg} / \mathrm{m}^{2}\right)$ & 57 & 21.4 & 32 & 19.5 & 25 & 24.3 & \\
\hline Overweight $\left(25-30 \mathrm{~kg} / \mathrm{m}^{2}\right)$ & 124 & 46.4 & 79 & 48.2 & 45 & 43.7 & \\
\hline Obese $\left(>30 \mathrm{~kg} / \mathrm{m}^{2}\right)$ & 86 & 32.2 & 53 & 32.3 & 33 & 32.0 & \\
\hline Smokers ${ }^{\mathrm{IV}}$ : & & & & & & & 0.000 \\
\hline Yes & 71 & 26.8 & 30 & 18.3 & 41 & 40.6 & \\
\hline No & 194 & 73.2 & 134 & 81.7 & 60 & 59.4 & \\
\hline Self-perceived health ${ }^{\mathrm{V}}$ : & & & & & & & 0.675 \\
\hline Good & 164 & 62.6 & 98 & 61.3 & 66 & 64.1 & \\
\hline Fairly & 79 & 30.0 & 48 & 30.0 & 31 & 30.1 & \\
\hline Poor & 20 & 7.6 & 14 & 8.8 & 6 & 5.8 & \\
\hline
\end{tabular}

'Missings: 2; "Missings: 8; "'Missings: 3; 'VMissings: 5; 'Missings: 7; *Chi-square test

Table 3. Work positions preformed more than half the time when working in fishery - cross sectional survey 2015

\begin{tabular}{lll}
\hline & N & $\%$ \\
\hline Standing & 220 & 81.8 \\
Same repeated hand and finger movements & 185 & 72.8 \\
Twisting and bending in the back & 117 & 43.7 \\
Carrying or lifting & 92 & 36.4 \\
Back sharply bent forward without support of hands and arms & 73 & 27.4 \\
Pushing or pulling & 71 & 26.7 \\
Hands lifted above shoulder height & 20 & 7.7
\end{tabular}

pers. The $p$-value $(0.0061)$ shows that the difference between skippers and deckhands are significant. There was also a significant difference ( $p=0.0016)$ between the crew on board the different vessel types. In particular, the mean values show that crew on Danish seiners has higher workload scores, but crews on netters, liners, and potters also have increased workload scores compared to crews on trawlers.

Tables 5 and 6 show questions and answers regarding work conditions for standing and lifting, respectively.
Standing work was required by $95.8 \%$ of the responding fishermen, while $71.5 \%$ found that variation in work and work postures is possible, and $72.0 \%$ regarded the work area as convenient (Table 5). Almost all fishermen (96.2\%) knew how to lift properly, but only about half of them (55.4\%) actually used proper lifting techniques in their daily work. About half of the fishermen (52.4\%) had an option for using assistive devices when lifting heavy items (Table 6). 
Table 4. Work load score divided between occupational groups, vessel types and number of days at sea - cross sectional survey 2015

\begin{tabular}{|c|c|c|c|}
\hline & \multicolumn{3}{|c|}{ Work load score $\#$} \\
\hline & $\mathbf{N}$ & Mean (SD) & $\mathbf{P}^{\# \#}$ \\
\hline Occupational groups: & & & 0.0061 \\
\hline Skipper & 165 & $23.3(6.2)$ & \\
\hline Deckhands* & 102 & $25.5(6.1)$ & \\
\hline Vessel type: & & & 0.0016 \\
\hline Trawler & 116 & $22.7(6.3)$ & \\
\hline Danish seiners & 14 & $27.1(5.6)$ & \\
\hline Netters and liners & 75 & $25.8(5.6)$ & \\
\hline Potters & 27 & $25.6(6.5)$ & \\
\hline Others** & 35 & $23.3(6.1)$ & \\
\hline Number of days at sea: & & & 0.5294 \\
\hline 1 & 123 & $24.5(5.6)$ & \\
\hline $1-7$ & 89 & $23.9(6.3)$ & \\
\hline More than 7 & 43 & $23.3(7.6)$ & \\
\hline
\end{tabular}

*Includes all other job categories (deckhands, trainees, cooks and missings); **Includes purse seiners and multi-purpose vessels, other vessels and missings: \#Missing: 3; \#\#ANOVA

Table 5. Work conditions for standing work - cross sectional survey 2015

\begin{tabular}{lll}
\hline Questions & Yes & No \\
\hline 1: Are the visual conditions good? & $95.8 \%$ & $4.2 \%$ \\
2: Is variation in work and work & $71.5 \%$ & $28.5 \%$ \\
postures possible? & & \\
3: Is the work area convenient? & $72.0 \%$ & $28.1 \%$ \\
4: Is standing work necessary? & $95.0 \%$ & $5.0 \%$
\end{tabular}

Table 6. Work conditions for lifting work - cross sectional survey 2015

\begin{tabular}{lll}
\hline Questions & Yes & No \\
\hline 1: Do you know how to lift properly? & $96.2 \%$ & $3.8 \%$ \\
$\begin{array}{l}\text { 2: Is it possible to use proper lifting } \\
\text { techniques in your work? }\end{array}$ & $57.4 \%$ & $42.6 \%$ \\
$\begin{array}{l}\text { 3: Do you use proper lifting techniques? } \\
\text { 4: Is it possible to use assistive devices }\end{array}$ & $55.4 \%$ & $44.6 \%$ \\
for heavy lifting? & $52.4 \%$ & $47.6 \%$ \\
$\begin{array}{l}\text { 5: Do you use assistive devices for heavy } \\
\text { lifting? }\end{array}$ & $40.7 \%$ & $59.3 \%$ \\
\end{tabular}

\section{DISCUSSION}

Approximately $70 \%$ of the responding fishermen reported a possibility for varied work postures while standing. This is largely supported by the positive developments that have occurred in the fishery in recent years, where much has been done to improve the fishermen's safety culture and work environment [4, 5]. However, looking at the working conditions for lifting work, it appears that almost everyone knows how to lift correctly, but in spite of this knowledge, only about half of the respondents used proper lifting techniques during work. This observation indicates that in spite of knowledge about the correct work postures, the fishermen may have difficulty translating the knowledge into practice and implementing it into their daily work.

The persistently high workload of Danish commercial fishermen shows that fishery remains a physically demanding profession, despite the many developments made in the field. The significant difference between the workload scores of skippers compared to deckhands may reflect the difference between the work tasks of the skipper and the other crew members on fishing vessels with more than one crew on board. The skipper's job involves carrying out the function as the navigator in charge and as planner and organizer of the daily operations of the fishing vessel [14]. The primary task of the deckhands is to perform the practical work on board the fishing vessel, which includes dealing with shooting and hauling of fishing gear as well as cleaning and icing of the catch [15]. With regards to vessel types, trawlers have the lowest workload score, while fishermen on the Danish seiners have the highest scores, which is where the difference is found to be significant. This can be explained by the fact that seine fishing is more manually demanding than fishing with trawl, which is more mechanical. Fishing seine requires the hauling to be adjusted while the fish is manually sorted and boxes are handled for icing. Today, trawling is mostly performed on larger vessels with more mechanical aids [10]. The workload scores for the number of days spent at sea show that fewer days spent at sea fishing equals a higher workload score. Although one might expect the opposite, one explanation may be that the less mechanical fishing vessels tend to be active for one day at a time, resulting in higher workload scores [10]. However this result is not significant.

According to the literature within this area, the fishermen's perceived workload and musculoskeletal pain are closely linked to the presence of musculoskeletal disorders [16], which have a higher prevalence among fishermen [17]. The symptoms follow a logical pattern according to type of fishing and type of work tasks on board where a larger workload leads to higher prevalence and incidence of symptoms/ /discomfort as well as musculoskeletal constraints [18]. The distribution of work tasks shows the frequency of hand and finger movements, while standing work, twisting and bending in the back and carrying or lifting, are also common. The work postures are often described as monotonous and repetitive work, which increases the risk of developing pain in the musculoskeletal system [9]. 
The statistical analyses are based on data from 270 Danish commercial fishermen (response rate: $28.15 \%$ ). The respondents constitute a random sample of the total number of commercial fishermen in Denmark. The participating fishermen are between 17 to 80 years, with an average age of 53.2 years. The Agrifish Agency states that according to their individual records based on civil registration information, the average age is 49.4 years in 2014 [19]. This means that the older generation of fishermen is slightly over-represented in this study. It is known that the average crew size on Danish fishing vessels is 1.3 [20], and while larger vessels in general often have more than 1.3 crewmembers, we can assume that deckhands might be over-represented among the respondents, according to the national average supplied by the Danish authorities.

While a final response rate of $28.2 \%$ in this study may present some limitations, the presence of a healthy worker effect may further influence the findings. Healthy worker effect causes an overrepresentation of healthy respondents, because ill and disabled persons are often not active in the labour market [21].

Low response rates are generally seen in cross-sectional questionnaire studies, however response rates up to $65 \%$ have been reported [3]. Percin et al [17] and Novalbos et al. [22] only achieved questionnaire response rates of $20 \%$ and about 3\%, respectively in ports in the Aegean Sea and Andalusia, Spain. The variance in response rate can be caused by multiple factors, and a study of Ruyter et al. 2004 [23] suggests that short surveys achieve higher response rates than longer questionnaires. The questionnaire in this study had 93 questions spread over 17 pages, thus falling within the latter category. Long questionnaires may in particular discourage this target group, which mainly consists of unskilled and low-skilled workers. The sample of Danish fishermen was randomly extracted from The Danish AgriFish Agency register of active and currently passive fishermen. As the register was supplied by The Danish AgriFish Agency, the number of currently passive fishermen that should be excluded in the study was not known in advance. This knowledge was only achieved when the questionnaires were returned, and could not have been predicted. A 'healthy-worker effect' in this study may have caused an overrepresentation of healthy and currently active fishermen at the time of the survey, as only active fishermen are included in the study. Consequently, fishermen who were incapable of working as fishermen due to health issues or have terminated the profession to work in other professions may not be represented in the study [24]. However results from a recent pilot study by Christiansen and Carlsbæk [25] suggest that fishermen tend to quit the industry due to issues such as quotas and economy rather than due to poor health and pain. Despite some limitations in the study, the core strength of this study is that this is the only recent cross-sectional study of ergonomic factors and workload of Danish fishermen that has been conducted following several structural and organizational changes in the fishing industry.

\section{CONCLUSIONS}

Despite the positive development of the physical work environment and safety culture in the fishing industry over the last decade, the fishermen still experience high levels of workload and suboptimal ergonomic conditions. Inexpedient work situations are still a big part of the work in the fishing industry for a large group, in spite of knowledge about correct work postures. This indicates that the fishermen may have difficulty translating the knowledge into practice and implementing it into their daily work.

From our results we can derive that future investments in assistive devices should facilitate the work of deckhands with a special focus on the most frequently performed work situations on board the vessels. In addition, investing in low-cost assistive devices for the less mechanized vessels would be beneficial, so small vessels with less profit also can afford to invest in devices that can facilitate the demanding manual labour and reduce the workload, which is known to cause pain and musculoskeletal health effects.

We further recommend future follow-up studies to focus on the causal effect of workload and musculoskeletal disorders in the changing fishery.

\section{REFERENCES}

1. Poulsen TR, Burr H, Hansen HL, Jepsen JR. Health of Danish seafarers and fishermen 1970-2010: What have register-based studies found? Scandinavian J Public Health 2014; 42: 534-545. doi: 10.1177/1403494814534538.

2. Kaerlev L, Dahl S, Nielsen PS et al. Hospital contacts for chronic diseases among Danish seafarers and fishermen: a population-based cohort study. Scand J Public Health 2007; 3: 481-489. doi: 10.1080/14034940701267385.

3. Jensen OC. Work related injuries in Danish fishermen. Occup Med (Lond) 1996; 46: 414-420. doi: 10.1093/occmed/46.6.414.

4. Christiansen JM, Carlsbæk AB. Omvæltninger og det psykiske arbejdsmiljø i fiskeriet - i ord og tal. Esbjerg: Centre of Maritime Health and Society, University of Southern Denmark, 2015.

5. Grøn S, Rasmussen HB, Poulsen TR, Nygaard Christensen F. Sikkerhed i fiskerierhvervet. Esbjerg: Centre of Maritime Health and Society, University of Southern Denmark 2014.

6. McGuinness E, Aasjord HL, Utne IB, Holmen IM. Injuries in the commercial fishing fleet of Norway 2000-2011. Safety Science 2013; 57: 82-99. doi: 10.1016/j.ssci.2013.01.008.

7. Jensen OC. Injury risk at the work processes in fishing: a case-referent study. Eur J Epidemiol 2006; 21: 521-527. doi: 10.1007/ s10654-006-9026-9.

8. Törner M, Almstrom C, Karlsson R, Kadefors R. Working on a moving surface-a biomechanical analysis of musculoskeletal load due to ship motions in combination with work. Ergonomics 1994; 37: 345-362.

9. Arbejdstilsynet (DK) Arbejdsrelateret muskel- og skeletbevær. [Internet] København (Denmark): Arbejdstilsynet (DK); 2005 [Cited 
2016 Feb 15]. Available from: https://arbejdstilsynet.dk/da/regler/ at-vejledninger/a/d-3-4-arbejdsrelateret-muskel-og-skeletbesvaer.

10. Johansen JP. Rygbelasninger i fiskeriet - vurdering af belastninger inden for fiskerierhvervet særligt med henblik på rygbelastninger. Aalborg: Arbejdsmedicinsk klinik, Ålborg Sygehus 1998.

11. Østergaard H, Poulsen TR, Remmen LN, Berg-Beckhoff G. Ergonomisk arbejdsmiljø, fysisk belastning og fatigue på danske fiskefartøjer. Esbjerg: Centre of Maritime Health and Society, University of Sothern Denmark 2015.

12. Holtermann A, Jorgensen MB, Gram B et al. Worksite interventions for preventing physical deterioration among employees in job-groups with high physical work demands: background, design and conceptual model of FINALE. BMC Public Health 2010; 10: 120-132. doi: 10.1186/1471-2458-10-120.

13. Santos J, Reynaldo A. Cronbach's Alpha: a tool for assessing the reliability of scales. J Extension 1999; 37.

14. Uddannelses- og Forskningsministeriet (DK) Bekendtgørelse om uddannelsen til fiskeskipper af 3. grad. [Internet] København (Denmark): Uddannelses- og Forskningsministeriet (DK); 2012 [Cited 2016 Mar 9]. Available from: https://www.retsinformation. $\mathrm{dk} /$ Forms/R0710.aspx?id=144114.

15. Uddannelses- og Forskningsministeriet (DK) Bekendtgørelse om erhvervsfiskeriets grundkursus. [Internet] København (Denmark): Uddannelses-og Forskningsministeriet(DK); 2015 [Cited 2016 Mar 9]. Available from: https://www.retsinformation.dk/Forms/R0710.aspx?id=173965.

16. Kaerlev L, Jensen A, Nielsen PS, Olsen J, Hannerz H, Tuchsen F. Hospital contacts for injuries and musculoskeletal diseases among seamen and fishermen: a population-based cohort study. BMC Musculoskeletal Disorders 2008; 9: 8-19. doi: 10.1186/1471. 2474-9-8.
17. Percin F, Akyol O, Davas A, Saygi H. Occupational health of Turkish Aegean small-scale fishermen. Occup Med (Lond) 2012; 62: 148-151. doi: 10.1093/occmed/kqr181.

18. Törner M, Blide G, Eriksson $\mathrm{H}$ et al. Musculoskeletal symptoms as related to working conditions among Swedish professional fishermen. Applied Ergonomics. 1988; 19: 191-201.

19. NaturErhvervsstyrelsen (DK) Alder- og Beskæftigelsesstatistik. [Internet] København (Denmark): Ministeriet for Fødevarer, Landbrug og fiskeri - NaturErhvervsstyrelsen (DK); 2016 [Cited 2016 Mar 25]. Available from: http://naturerhverv.dk/fiskeri/fiskeristatistik/alder -og-beskaeftigelsesstatistik/\#c9810.

20. NaturErhvervsstyrelsen (DK) Fiskeristatistisk Årbog 2014. [Internet] København (Denmark): Ministeriet for Fødevarer, Landbrug og fiskeri-NaturErhvervsstyrelsen (DK); 2013 [Cited 2016 May 2]. Available from: http://webfd.fd.dk/info/sjle3/fsa_bog2014/Fiskeristatistisk.pdf.

21. Shah D. Healthy worker effect phenomenon. Indian J Occup Environ Med 2009; 13: 77-79. doi: 10.4103/0019-5278.55123.

22. Novalbos J, Nogueroles $P$, Soriguer M, Piniella F. Occupational health in the Andalusian Fisheries Sector. Occup Med (Lond) 2008; 58: 141-143. doi: 10.1093/occmed/kqm156.

23. Deutskens E, de Ruyter K, Wetzels M, Oosterveld P. Response rate and response quality of internet-based surveys: an experimental study. Marketing Letters 2004; 15: 21-36. doi: 10.1023/B:MA RK.0000021968.86465.00.

24. Aschengrau A, Seage GR. Essentials of epidemiology in public health. Sudbury, Mass: Jones and Bartlett Learning 2003.

25. Christiansen JM, Carlsbæk AB. Fiskerne der forsvandt. Esbjerg: Centre of Maritime Health and Society, University of Southern Denmark 2015. 